\title{
Effect of polishing methods on color change by water absorption in several composite resins
}

\author{
Hye Jin Kim, Mi-yeon Kim, Byung-chul Song, Sun-ho Kim, Jeong-hee Kim* \\ Department of Conservative Dentistry, Veterans Health Service Medical Center, Seoul, Republic of Korea
}

Purpose: The aim of this study was to evaluate the influence of polishing methods on the color stability of composite resins. Materials and Methods: Two bulk-fill and four conventional resin composites were filled in cylindrical molds ( $6 \mathrm{~mm}$ diameter, $4 \mathrm{~mm}$ height) and light-cured. The specimens were stored in $34^{\circ} \mathrm{C}$ distilled water for $24 \mathrm{~h}$. Spectrophotometer was used to determine the color value according to the CIE $L^{*} a^{*} b^{*}$ color space. Each group was divided into three groups according to polishing methods (n =5). Group 1 was control group (Mylar strip group), group 2 was polished with PoGo, and group 3 was polished with Sof-Lex Spiral wheels. Color evaluation was performed weekly for 4 weeks after immersion in $34^{\circ} \mathrm{C}$ distilled water. The results were analyzed by generalized least squares method $(P<0.05)$. Results: Generalized least squares analysis revealed that Sof-Lex Spiral wheels group showed the significantly lower $\Delta E$ values compared to PoGo and control group $(P<0.05)$. The $\Delta E$ values of polished group showed the significantly lower than the $\Delta E$ values of unpolished group $(P<0.05)$. Regarding color changes of composite resins, there was no significant difference between the $\Delta E$ values of Filtek Z250 and Filtek Z350 XT Universal restorative in all time intervals $(P<0.05)$. Tetric N-Ceram Bulk Fill showed the significantly lower $\Delta E$ values compared to other composite resins in $1,2,3$ weeks $(P<0.05)$. Conclusion: Within the limitations of this study, polishing methods influence the color stabilities of composite resins. The group polished with Sof-Lex Spiral Wheels showed more resistance to discoloration than group polished with PoGo. (J Dent Rehabil Appl Sci 2019;35(1):1-10)

Key words: bulk-fill resin; color stability; composite resins; polishing methods; Sof-Lex Spiral wheels

\section{Introduction}

With the development of filler and chemical compositions, composite resins can be successfully used in posterior restorations. However, composite resins could be discolored with time and this could be the reason of replacement. Color stability of composite resins is affected by composition of composite resins and polishing methods. ${ }^{1,2}$

Discolored resin composites in restorations should be replaced for esthetic consideration. The color sta-

*Correspondence to: Jeong-hee Kim

Professor, Department of Conservative Dentistry, Veterans Health Service Medical Center, 53 Jinhwangdo-ro 61-gil, Gangdong-gu, Seoul, 05368, Korea Tel: +82-2-2225-1925, Fax: +82-2-2225-1659, E-mail: endo95@naver.com Received: August 18, 2018/Last Revision: December 2, 2018/Accepted: December 3, 2018 bility of a composite resin depends on both extrinsic and intrinsic factors. The intrinsic factors include the discoloration of the resin material itself, such as alterations in the resin matrix and the matrix-filler interface. The discoloration susceptibility of composite resins might depend on the hydrophilic/hydrophobic characteristic of composite resins and the percentage of hydrophilic materials. ${ }^{3}$ The staining of composite resins could be due to water absorption and water absorption occurs mainly as direct absorption by hydrophilic materials. ${ }^{3}$ For example, TEGDMA 
is one of the compositions of matrix of composite resins and has characteristic of hydrophilicity. ${ }^{4}$ This hydrophilic material could be stained by hydrophilic colorants to a greater degree than hydrophobic materials and considered as a factor of discoloration. ${ }^{4}$ Extrinsic factors include staining by the absorption and adsorption of colorants through contamination by various exogenous sources. ${ }^{3}$ Biofilm accumulation on the restoration surface could induce penetration of colorant and reaction between dye agent and surface layer of composite resins. ${ }^{1}$ Polishing procedure of composite resins could reduce surface roughness of restoration and consequently could be attribute to color stability of composite resins by reducing accumulation of biofilm. ${ }^{1}$

Various finishing and polishing systems for resin composites have been introduced to reduce the surface roughness and increase the color stability of restoratives. The diamond point, abrasive disk, and abrasive finishing strips are used in finishing and polishing. PoGo (Dentsply Caulk, Milford, USA) is a single-step finishing and polishing system made of a flexible micro-polisher disk containing fine diamond particles. On the other hand, Sof-Lex discs are flexible aluminum oxide with roughness classification of Coarse $(55 \mu \mathrm{m})$, Medium $(40 \mu \mathrm{m})$, Fine $(24 \mu \mathrm{m})$, SuperFine $(8 \mu \mathrm{m})$. Recently, Sof-Lex Spiral wheels (3M ESPE, St. Paul, USA) were introduced for both anterior and posterior restoratives, using a flexible disk wheel. The polishing system uses two steps and comprises an elastomeric wheel containing aluminum oxide powder particles comprising one beige and one white wheel. ${ }^{5,6}$ The flexibility of the wheels enables variable angles of approach to the restorative, allowing use with both posterior and anterior restoratives. ${ }^{7,8}$

Conventional resins should be applied in 2- $\mathrm{mm}$ increments to reduce polymerization shrinkage, which is a time-consuming procedure. Recently, bulk-fill composite resins have been introduced: these materials are sufficiently light-cured in increments reaching $4 \mathrm{~mm}$. In addition, high-viscosity bulk-fill resin composites are reported to have less polymerization shrinkage, higher degrees of curing, and similar mechanical properties compared to conventional composite resins.
The use of bulk-fill resin composites could reduce the time of clinical procedures and minimize technical problems such as gap formation, postoperative sensitivity, and recurrent caries. The reduced polymerization shrinkage of bulk-fill resin composites permits greater light transmission by increasing the translucency and by using stress-relieving monomers and different types of fillers, including prepolymer particles and fiberglass rod segments. ${ }^{10}$

Measuring the color changes of composite resins is performed by visual inspection or the use of colorimeters and spectrometers. Color change assessment by visual determination is subjective and low in reproducibility. However, using a colorimeter or spectrophotometer allows the representation of color changes by objective numbers. These apparatus are considered effective and highly reproducible in measuring color changes because they are rarely affected by environmental factors. ${ }^{11}$

The aim of this study is to evaluate the effects of different polishing methods on the color stabilities of bulk- and incremental-fill resin composites for 4 weeks after immersion in distilled water.

\section{Materials and Methods}

Resin-based composites used in the study are presented in Table 1. Two bulk-fill (Filtek Bulk Fill Posterior A2 shade, 3M ESPE, St. Paul, USA; Tetric N-Ceram Bulk Fill IVA shade, Ivoclar Vivadent, Schaan, Liechtenstein) and four conventional resin composites (Filtek Z250 A2 shade, 3M ESPE, St. Paul, USA; Filtek Z350 XT Universal restorative A2 shade, 3M ESPE, St. Paul, USA; Filtek Z350 Flowable restorative A2 shade, 3M ESPE, St. Paul, USA; Grandio A2 shade, VoCo, Cuxhaven, Germany) were used. The shades were A2 for the other composite resins and IVA for Tetric N-Ceram Bulk Fill.

The specimens of conventional and bulk-fill composite resins $(6 \mathrm{~mm}$ diameter and $4 \mathrm{~mm}$ thickness, $\mathrm{n}$ $=5$ ) were prepared using a polyethylene mold. After applying the composite resins, the upper and bottom surfaces of the mold were covered by Mylar strips and pressed with glass slabs to obtain a flat surface and prevent oxygen inhibition layer. The glass slab 
Table 1. Composition of the materials used in the study

\begin{tabular}{|c|c|c|c|c|c|c|c|}
\hline Resin & Shade & $\begin{array}{l}\text { Filler } \\
\text { weight } \\
(\%)\end{array}$ & $\begin{array}{l}\text { Filler } \\
\text { volume } \\
(\%)\end{array}$ & Filler type & Filler size & $\begin{array}{l}\text { Monomer } \\
\text { composition }\end{array}$ & Manufacturer \\
\hline \multicolumn{8}{|c|}{ Conventional incremental-fill resins } \\
\hline $\begin{array}{l}\text { Filtek Z250 } \\
\text { (microhybrid) }\end{array}$ & $\mathrm{A} 2$ & 84.5 & 60 & Zirconia/silica & $\begin{array}{c}0.01-3.5 \mu \mathrm{m} \\
\text { (average } 0.6 \mu \mathrm{m} \text { ) }\end{array}$ & $\begin{array}{l}\text { Bis-GMA, } \\
\text { Bis-EMA, } \\
\text { UDMA }\end{array}$ & $\begin{array}{l}\text { 3M ESPE, } \\
\text { St. Paul, } \\
\text { USA }\end{array}$ \\
\hline $\begin{array}{l}\text { Filtek Z350 XT } \\
\text { Universal } \\
\text { restorative }\end{array}$ & $\mathrm{A} 2$ & 82 & 59.5 & $\begin{array}{l}\text { Combination of } \\
\text { aggregate zirconia/ } \\
\text { silica cluster filler and } \\
\text { non-agglomerated } \\
20 \mathrm{~nm} \text { silica filler }\end{array}$ & $0.005-0.02 \mu \mathrm{m}$ & $\begin{array}{l}\text { Bis-GMA, } \\
\text { Bis-EMA, } \\
\text { UDMA, } \\
\text { TEGDMA }\end{array}$ & $\begin{array}{l}\text { 3M ESPE, } \\
\text { St. Paul, } \\
\text { USA }\end{array}$ \\
\hline $\begin{array}{l}\text { Filtek Z350 XT } \\
\text { Flowable } \\
\text { restorative }\end{array}$ & A2 & 65 & 55 & $\begin{array}{l}\text { Zirconia, silica, } \\
\text { silane-treated } \\
\text { ceramic }\end{array}$ & $\begin{array}{l}\text { Silica: } 20 \mathrm{~nm}, \\
\text { Zirconia: } 4-11 \mathrm{~nm}\end{array}$ & $\begin{array}{l}\text { Bis-GMA, } \\
\text { Bis-EMA, } \\
\text { TEGDMA }\end{array}$ & $\begin{array}{l}\text { 3M ESPE, } \\
\text { St. Paul, } \\
\text { USA }\end{array}$ \\
\hline $\begin{array}{l}\text { Grandio } \\
\text { (nanohybrid) }\end{array}$ & A2 & 87 & 71.4 & $\begin{array}{l}\text { Barium-alumino- } \\
\text { borosilicate; } \\
\text { fumed silica }\end{array}$ & $\begin{array}{l}\text { Glass-ceramic } \\
\text { micro-filler: } 1000 \mathrm{~nm} \text {, } \\
\text { Nanofiller: } 20-50 \mathrm{~nm}\end{array}$ & $\begin{array}{l}\text { Bis-GMA, } \\
\text { TEGDMA, } \\
\text { UDMA }\end{array}$ & $\begin{array}{l}\text { VoCo, } \\
\text { Cuxhaven, } \\
\text { Germany }\end{array}$ \\
\hline \multicolumn{8}{|l|}{ Bulk-fill resins } \\
\hline Filtek Bulk Fill & A2 & 76.5 & 58.4 & $\begin{array}{l}\text { Non-aggregated } \\
\text { zirconia and silica filler, } \\
\text { aggregated zirconia/ } \\
\text { silica cluster filler, } \\
\text { ytterbium trifluoride }\end{array}$ & $\begin{array}{c}\text { Non-aggregated } \\
\text { silica filler: } 20 \mathrm{~nm}, \\
\text { non-aggregated zirconia } \\
\text { filler: } 4-11 \mathrm{~nm}, \\
\text { aggregated zirconia/ } \\
\text { silica: } 4-11 \mathrm{~nm} \text {, } \\
\text { zirconia: } 0.6-10 \mu \mathrm{m}\end{array}$ & $\begin{array}{l}\text { Bis-GMA, } \\
\text { Bis-EMA, } \\
\text { UDMA, } \\
\text { AUDMA, } \\
\text { DDDMA }\end{array}$ & $\begin{array}{l}\text { 3M ESPE, } \\
\text { St. Paul, } \\
\text { USA }\end{array}$ \\
\hline $\begin{array}{l}\text { Tetric N-Ceram } \\
\text { Bulk Fill }\end{array}$ & IVA & $75-77$ & $53-55$ & $\begin{array}{l}\text { Barium glass filler, } \\
\text { ytterbium trifluoride, } \\
\text { Silica }\end{array}$ & $0.6 \mu \mathrm{m}$ & $\begin{array}{l}\text { Bis-GMA, } \\
\text { Bis-EMA, } \\
\text { UDMA }\end{array}$ & $\begin{array}{l}\text { Ivoclar- } \\
\text { Vivadent, } \\
\text { Schaan, } \\
\text { Liechtenstein }\end{array}$ \\
\hline
\end{tabular}

Bis-GMA: Bisphenol A glycidylmethacrylate; UDMA: Urethane dimethacrylate; Bis-EMA: Ethoxylatedbisphenol A glycol dimethacrylate; AUDMA: Aromatic dimethacrylate; TEGDMA: Triethylene glycol dimethacrylate; DDDMA: 1,12-dodecanediol dimethacrylate.

Table 2. Compositions of the polishing systems

\begin{tabular}{ccc}
\hline Finishing and Polishing system & Composition & Manufacturer \\
\hline Mylar strip & Polyester & Henry Schein, Melville, USA \\
PoGo & $\begin{array}{c}\text { Cured composite of urethane dimethacrylate, } \\
\text { fine diamond powder, silicon dioxide } 7 \mu \mathrm{m}, \mathrm{Al}_{2} \mathrm{O}_{3}\end{array}$ & Dentsply Caulk, Milford, USA \\
Elastomer impregnated with aluminum oxide particles & 3M ESPE, St. Paul, USA \\
& $(25-29 \mu \mathrm{m})$ & \\
\hline
\end{tabular}

was removed and the specimens were polymerized using a light-emitting diode curing unit (Smart Light, DentsplyDentsply Caulk, Milford, USA) placed in contact with the surface of the specimen. The incremental filling technique was used for the conventional resin composites with two cycles of 2 -mm application and $20 \mathrm{~s}$ light curing. The bulk-fill resin composites were filled the molds in a single 4-mm application and $40 \mathrm{~s}$ light curing. And the other side of the specimen was also cured for $40 \mathrm{~s}$ for preventing insufficient polymerization. The specimens were stored in $34^{\circ} \mathrm{C}$ distilled water for $24 \mathrm{~h}$ and polished with one of the polishing procedures including PoGo and Sof-Lex Spiral wheels (Table 2). In PoGo 
polishing group, Point shaped Pogo was applied for $20 \mathrm{~s}$ with water. In the Sof-Lex Spiral wheels group, a fine finishing Sof-Lex Spiral wheel (beige) and superfine polishing wheel (white) were applied for $20 \mathrm{~s}$ each without water according to the manufacturer's instructions. Control group was the specimens made by Mylar strip without polishing. Specimens were stored in $34^{\circ} \mathrm{C}$ distilled water for 4 weeks in well plates (10 $\mathrm{mm}$ holes) to avoid mixing up. The distilled water was replaced every week and maintained at $34^{\circ} \mathrm{C}$ using a thermostat (PhilGreen, Chaungxing Co., China). Color evaluation was performed after polishing as baseline and then after 1, 2, 3, and 4 weeks of immersion in distilled water. Color measurements of the specimen surfaces were obtained using a spectrophotometer (NF 999, Nippon Denshoku, Japan) according to the CIE $L^{*} a^{*} b^{*}$ system. Before each measurement, all specimens were rinsed with distilled water for $5 \mathrm{~s}$ and blotted dried with tissue paper for removing excess water. Color measurements were performed for three times and the mean values of the data were calculated. The color changes were calculated using the $L^{*}, a^{*}$, and $b^{*}$ values for each specimen and expressed as $\Delta E$ in order to compare the baseline values by applying the formula.

$$
\Delta \mathrm{E}=\left[(\Delta \mathrm{L})^{2}+(\Delta \mathrm{a})^{2}+(\Delta \mathrm{b})^{2}\right]^{1 / 2}
$$

\section{Statistical analysis}

The results were statistically analyzed with the generalized least squares method using a Linear and Nonlinear Mixed Effects (nlme) model with factors including materials and polishing systems $(P<0.05)$ ( $\mathrm{R}$ software package, ver.3.4.1). The interactions between materials and time and between materials and polishing systems were not included in the model because did not show statistical significance.

\section{Results}

The mean (standard deviation) $\Delta E$ values of specimens with different polishing systems are shown in Table 3 and Fig. 1 - 4. The results of this study showed the significant color change among materials and polishing procedures $(P<0.05)$.

Generalized least squares analysis revealed that Sof-Lex Spiral wheels group showed the significantly lower $\Delta E$ values compared to PoGo and control group $(P<0.05$, Fig. $2-5)$. The $\Delta E$ values of polished group showed the significantly lower than the $\Delta E$ values of unpolished group $(P<0.05$, Fig. 2 - 5).

Regarding color changes of composite resins, there was no significant difference between the $\Delta E$ values of Filtek Z250 and Filtek Z350 XT Universal restorative in all time intervals $(P<0.05)$. Tetric $\mathrm{N}$-Ceram Bulk Fill showed the significantly lower $\Delta E$ values compared to other composite resins in 1, 2, 3 weeks $(P<0.05)$.

The highest color changes were observed when Filtek Z350 XT Universal restorative was not polished in 4 weeks. The lowest values overall are observed for Tetric N-Ceram Bulk Fill polished with Sof-Lex Spiral wheels in 4 weeks.

\section{Discussion}

The color stability of composite resins is an important factor in dental restoration. The discoloration of composite resins in a restoration is one reason for replacing extant restoratives: in addition, the color stability of composite resins is a deciding factor in material selecting.

Finishing and polishing of the composite resins affect their resistance to color change by reducing colorant absorbency. This is because the resin matrix emerges to the surface, which is rich in organic components. The resin matrix tends to absorb more water and is more prone to staining with water as the vehicle for dyes penetration. ${ }^{4,12,13}$

In this study, the control group presents more discoloration than the polished group. This is due to the presence of matrix rich in surface. Water absorption occurs mainly as direct absorption by the resin matrix. The polishing procedure removes matrix of resin surface and consequently could reduce the degree of discoloration. And the Sof-Lex Spiral wheels group exhibits lower $\Delta E$ than the PoGo group. This is explained by the smoother surface yielded by multi-step polishing is more resistant to discolor- 
Table 3. Mean values (SD) of color changes $(\Delta E)$ of the composite resins

\begin{tabular}{|c|c|c|c|c|}
\hline \multirow{2}{*}{ Material } & \multirow{2}{*}{ Time interval } & \multicolumn{3}{|c|}{ Polishing system } \\
\hline & & Control (Mylar) & PoGo & Sof-Lex Spiral wheels \\
\hline \multirow[t]{4}{*}{ Filtek Z250 } & $\Delta E_{1 \mathrm{wk}}$ & $3.22(0.96)^{\mathrm{Aa}}$ & $2.18(1.29)^{\mathrm{Ab}}$ & $1.88(0.74)^{\mathrm{Ac}}$ \\
\hline & $\Delta E_{2 \mathrm{wk}}$ & $4.31(1.05)^{\mathrm{Aa}}$ & $3.23(1.05)^{\mathrm{Ab}}$ & $3.19(0.99)^{\mathrm{Ac}}$ \\
\hline & $\Delta E_{3 \mathrm{wk}}$ & $3.89(1.06)^{\mathrm{Aa}}$ & $5.50(2.09)^{\mathrm{Ab}}$ & $4.84(1.09)^{\mathrm{Ac}}$ \\
\hline & $\Delta E_{4 \mathrm{wk}}$ & $4.95(1.33)^{\mathrm{Aa}}$ & $5.30(1.93)^{\mathrm{Ab}}$ & $4.88(1.43)^{A c}$ \\
\hline Filtek Z350 XT & $\Delta E_{1 \mathrm{wk}}$ & $5.10(0.94)^{\mathrm{Aa}}$ & $3.43(1.77)^{\mathrm{Ab}}$ & $2.29(0.94)^{\mathrm{Ac}}$ \\
\hline \multirow[t]{3}{*}{ Universal restorative } & $\Delta E_{2 \mathrm{wk}}$ & $6.01(1.80)^{\mathrm{Aa}}$ & $4.06(1.63)^{\mathrm{Ab}}$ & $3.00(0.55)^{A c}$ \\
\hline & $\Delta E_{3 \mathrm{wk}}$ & $6.69(2.72)^{A a}$ & $5.16(2.11)^{\mathrm{Ab}}$ & $4.03(0.46)^{A c}$ \\
\hline & $\Delta E_{4 \mathrm{wk}}$ & $7.62(2.15)^{\mathrm{Aa}}$ & $6.24(2.45)^{\mathrm{Ab}}$ & $4.70(0.52)^{A c}$ \\
\hline Filtek Z350 XT & $\Delta E_{1 \mathrm{wk}}$ & $1.89(0.57)^{\mathrm{Ba}}$ & $1.29(0.69)^{\mathrm{Bb}}$ & $0.79(0.37)^{\mathrm{Bc}}$ \\
\hline \multirow[t]{3}{*}{ Flowable restorative } & $\Delta E_{2 \mathrm{wk}}$ & $2.17(1.04)^{\mathrm{Ba}}$ & $1.80(0.31)^{\mathrm{Bb}}$ & $1.49(0.59)^{\mathrm{Bc}}$ \\
\hline & $\Delta E_{3 \mathrm{wk}}$ & $3.93(1.98)^{\mathrm{Ba}}$ & $2.17(0.28)^{\mathrm{Bb}}$ & $1.43(0.38)^{\mathrm{Bc}}$ \\
\hline & $\Delta E_{4 \mathrm{wk}}$ & $5.40(2.00)^{\mathrm{Ba}}$ & $2.66(0.73)^{\mathrm{Bb}}$ & $2.34(0.83)^{\mathrm{Bc}}$ \\
\hline \multirow[t]{4}{*}{ Grandio } & $\Delta E_{1 \mathrm{wk}}$ & $2.82(1.36)^{\mathrm{Ca}}$ & $1.60(0.35)^{\mathrm{Cb}}$ & $1.24(0.66)^{\mathrm{Cc}}$ \\
\hline & $\Delta E_{2 \mathrm{wk}}$ & $2.72(1.27)^{\mathrm{BCa}}$ & $2.05(0.70)^{\mathrm{BCb}}$ & $1.39(0.74)^{\mathrm{BCc}}$ \\
\hline & $\Delta E_{3 \mathrm{wk}}$ & $2.57(0.98)^{\mathrm{Ca}}$ & $1.76(0.59)^{\mathrm{Cb}}$ & $1.29(0.71)^{\mathrm{Cc}}$ \\
\hline & $\Delta E_{4 \mathrm{wk}}$ & $2.22(0.34)^{\mathrm{Ca}}$ & $1.55(0.89)^{\mathrm{Cb}}$ & $1.27(0.60)^{\mathrm{Cc}}$ \\
\hline \multirow[t]{4}{*}{ Filtek Bulk Fill } & $\Delta E_{1 \mathrm{wk}}$ & $1.77(0.68)^{\mathrm{Ca}}$ & $1.22(0.74)^{\mathrm{Cb}}$ & $1.20(0.41)^{\mathrm{Cc}}$ \\
\hline & $\Delta E_{2 \mathrm{wk}}$ & $2.92(1.01)^{\mathrm{Ca}}$ & $1.80(0.91)^{\mathrm{Cb}}$ & $1.67(0.56)^{\mathrm{Cc}}$ \\
\hline & $\Delta E_{3 \mathrm{wk}}$ & $3.21(0.65)^{\mathrm{Ba}}$ & $2.17(0.98)^{\mathrm{Bb}}$ & $1.84(0.47)^{\mathrm{Bc}}$ \\
\hline & $\Delta E_{4 \mathrm{wk}}$ & $3.46(1.11)^{\mathrm{Ba}}$ & $2.19(0.85)^{\mathrm{Bb}}$ & $1.93(0.9)^{\mathrm{Bc}}$ \\
\hline \multirow[t]{4}{*}{ Tetric N-Ceram Bulk Fill } & $\Delta E_{1 \mathrm{wk}}$ & $1.38(0.39)^{\mathrm{Da}}$ & $1.01(0.62)^{\mathrm{Db}}$ & $0.33(0.08)^{\mathrm{Dc}}$ \\
\hline & $\Delta E_{2 \mathrm{wk}}$ & $1.46(0.22)^{\mathrm{Da}}$ & $1.30(0.50)^{\mathrm{Db}}$ & $0.51(0.16)^{\mathrm{Dc}}$ \\
\hline & $\Delta E_{3 \mathrm{wk}}$ & $2.32(0.49)^{\mathrm{Da}}$ & $1.17(0.38)^{\mathrm{Db}}$ & $0.69(0.36)^{\mathrm{Dc}}$ \\
\hline & $\Delta E_{4 \mathrm{wk}}$ & $2.19(0.55)^{\mathrm{Ca}}$ & $1.39(0.56)^{\mathrm{Cb}}$ & $1.25(0.47)^{\mathrm{Cc}}$ \\
\hline
\end{tabular}

Same uppercase letters indicate insignificant differences between composite resins $(P<0.05)$.

Same lowercase letters indicate insignificant differences between polishing procedures $(P<0.05)$.

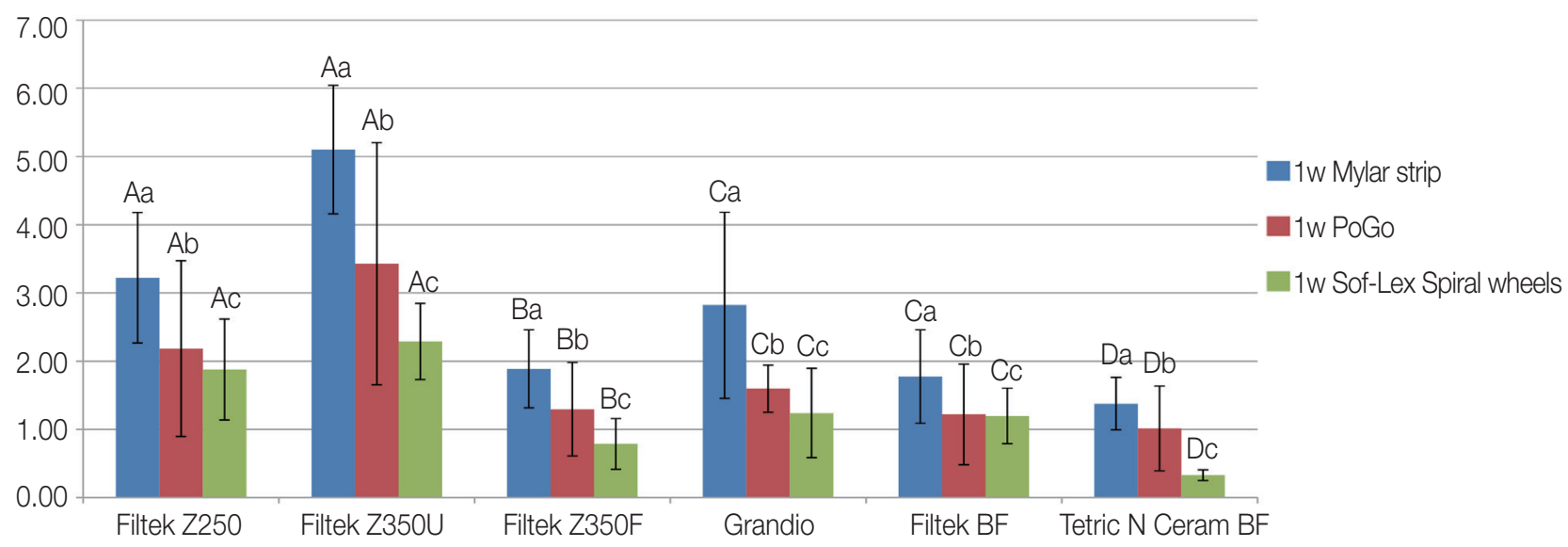

Fig. 1. Mean values $(S D)$ of color changes $(\Delta E)$ of the composite resins according to polishing system after 1 week. Same uppercase letters indicate insignificant differences between composite resins $(P<0.05)$. Same lowercase letters indicate insignificant differences between polishing procedures $(P<0.05)$. Filtek Z350U: Filtek Z350 Universal restorative; Filtek Z350F: Filtek Z350 Flowable restorative; Filtek BF: Filtek Bulk Fill; Tetric N Ceram BF: Tetric N-Ceram Bulk Fill. 


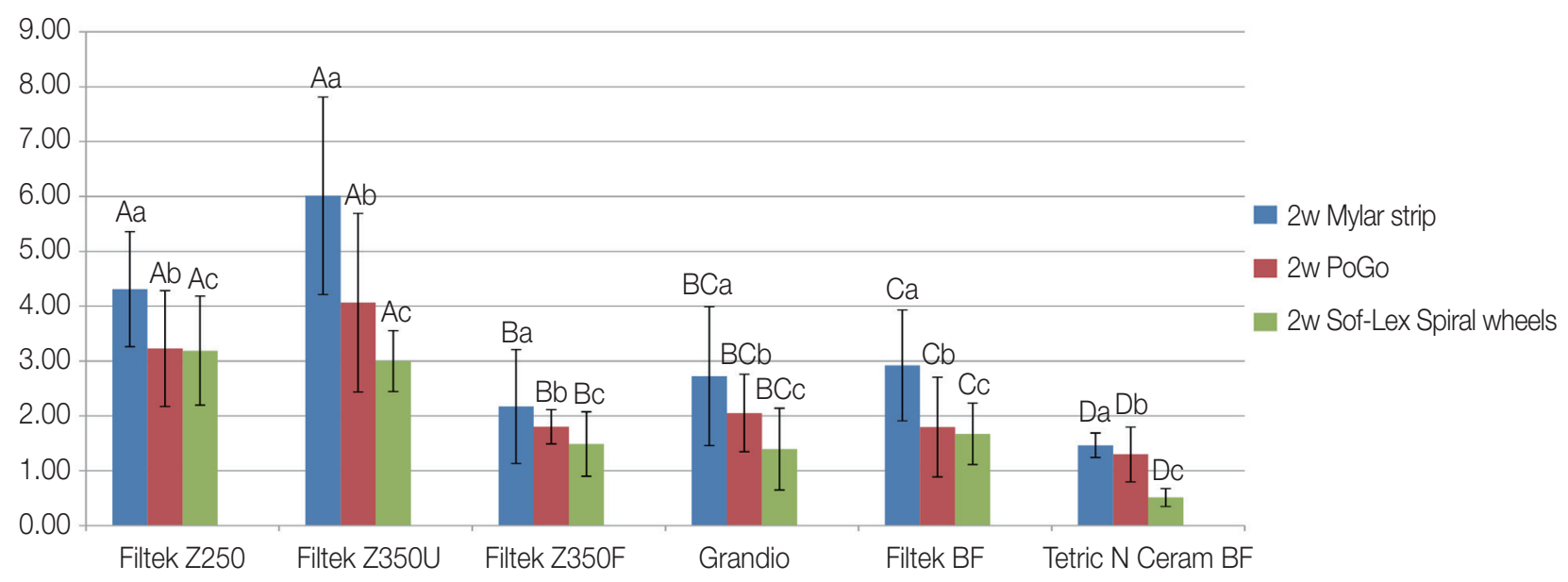

Fig. 2. Mean values (SD) of color changes $(\Delta E)$ of the composite resins according to polishing system after 2 weeks. Same uppercase letters indicate insignificant differences between composite resins $(P<0.05)$. Same lowercase letters indicate insignificant differences between polishing procedures $(P<0.05)$.

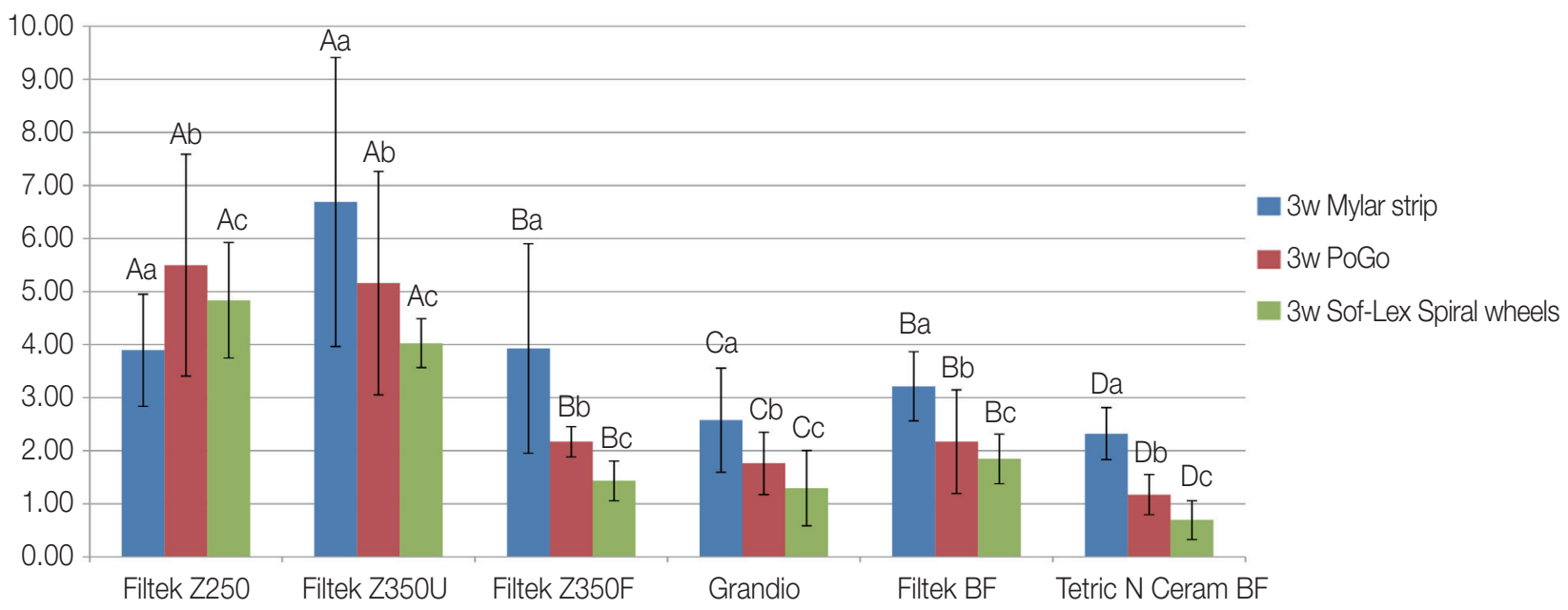

Fig. 3. Mean values (SD) of color changes $(\Delta E)$ of the composite resins according to polishing system after 3 weeks. Same uppercase letters indicate insignificant differences between composite resins $(P<0.05)$. Same lowercase letters indicate insignificant differences between polishing procedures $(P<0.05)$.

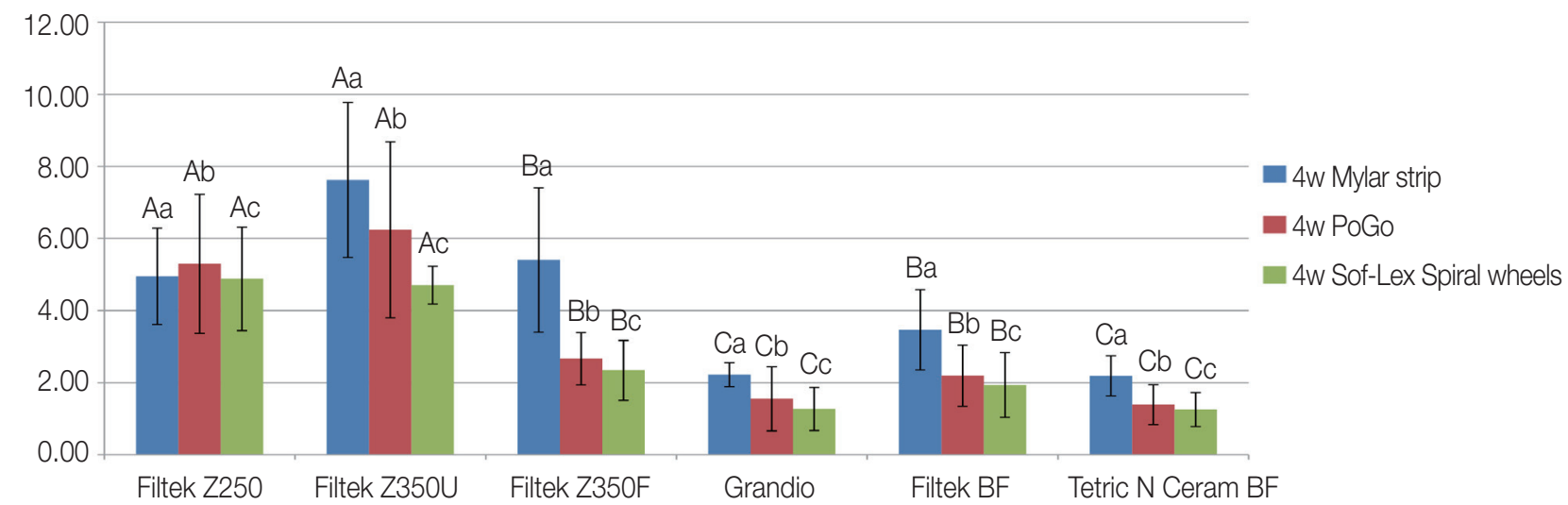

Fig. 4. Mean values (SD) of color changes $(\Delta E)$ of the composite resins according to polishing system after 4 weeks. Same uppercase letters indicate insignificant differences between composite resins $(P<0.05)$. Same lowercase letters indicate insignificant differences between polishing procedures $(P<0.05)$. 
ation. ${ }^{1}$ Although the difference of surface roughness induced by the different polishing systems was not investigated in this study, this result agrees with those of $\mathrm{Lu}$ et al. and Venturini et al. who reported that multi-step polishing techniques reduced filler and matrix similarly, thus reducing discoloration. ${ }^{14,15}$

It was also observed a significant difference between composite resins in this study. Filtek Z350 XT Universal restorative showed greater discoloration than other materials. This could be explained by characteristics of composite resin itself. Several studies have reported that staining of composite resins was generally associated with the hydrophilicity of the composite matrix. ${ }^{2}$ Composite resins contain BisGMA, Bis-EMA, UDMA, and TEGDMA as matrix. Sideridou et al. reported that hydrophilic materials were stained by hydrophilic colorants in aqueous solutions to a greater degree than hydrophobic materials were. ${ }^{16}$ The potential for discoloration depends on the absorbency characteristic of the matrix, which are $6.33,2.93,2.59$, and $1.79 \mathrm{wt} \%$ for TEGDMA, Bis-GMA, UDMA, and Bis-EMA respectively. ${ }^{16} \mathrm{Al}-$ though Filtek Z250 and Filtek Z350 XT Universal restorative have similar composition and percentages of filler, Filtek Z350 XT Universal restorative is more susceptible to staining than Filtek Z250. This is attributed to the high percentage of TEGDMA in Filtek Z350 XT Universal restorative. ${ }^{14}$ The hydrophilicity of the epoxy group in TEGDMA induces affinity to water molecules, promoting hydrogen bonding. ${ }^{7}$ The nano-filled composite of Filtek Z350 XT Universal restorative contains 5 - $20 \mathrm{~nm}$ aggregated zirconia/silica clusters and $20 \mathrm{~nm}$ non-aggregated silica as a filler. This material is more prone to absorb water than a microhybrid resin because the glass filler particles in composite resins have greater porosities. ${ }^{17,18}$ However, there are no significant difference between Filtek Z250 and Filtek Z350 XT Universal restorative in this study. Furthermore, Filtek Z350 XT Flowable restorative has similar filler and matrix composition compared to Filtek Z350 XT Universal restorative, it presents lower color change. It needs further investigations.

In the present study, Grandio showed lesser discoloration than Filtek Z250 and Filtek Z350 XT Univer- sal restorative. This could be explained by filler size, percentage of filler, and surface roughness of composite resins. Ertan et al. reported that filler particles could be plucked out leaving voids during finishing and polishing procedure. ${ }^{19}$ It has been reported that smaller particles in nanohybrid composite resins were shaved off and smaller voids were left on the surface as compared to the microhybrid composite resins. ${ }^{19}$ Therefore, nanohybrid materials showed a lower surface roughness value and greater discoloration resistance than the microhybrid materials. ${ }^{19}$ The resistant to discoloration of Grandio could be also affected by relatively high percentage of filler compared to Filtek Z350 XT Universal restorative.

In this study, the bulk-fill composite resins present similar or lower color changes compared to those of the conventional incremental-fill composite resins and Filtek Bulk Fill exhibits a greater color change than Tetric N-Ceram Bulk Fill, consistent with the report by Thumu et al. ${ }^{20}$ Filtek Bulk Fill has less filler and more nanoclusters, which is susceptible to water absorption than Tetric N-Ceram. ${ }^{20}$ Tetric N-Ceram Bulk Fill exhibits less color change than Filtek Z350 XT Universal restorative. This is explained by the filler composition of barium glass, and ytterbium fluoride, which are more resistant to color change than the zirconia filler in Filtek Z350 XT Universal restorative. $^{21}$

However, bulk-fill composite resins exhibited greater color changes than conventional resins in the study of Shamszadeh et al. ${ }^{3}$ Bulk-fill resin has various fillers, prepolymer shrinkage stress relievers, and special photo-initiator systems. These can induce high color change. The bulk-fill technique may also form a greater number of particle/resin matrix interfaces, with increased light scattering due to the differences in their refractive indices. Therefore, fewer photons reach the deep layers of the composite resin: consequently, a lower degree of curing would be obtained at the greatest depths from the surface.

There are various methods for color measurement such as visual inspection using shade guides, colorimetry, and spectrophotometry. Johnston et al. reported that the assessment of color change by visual inspection could be affected by the environment or 
the observer. ${ }^{22}$ However, Liberman et al. found that color measurements using spectrophotometer or colorimeter were objective, quantifiable, and reproducible. In this study, the measurement of discoloration used the CIE $L^{*} a^{*} b^{*}$ coordinate system. ${ }^{11}$ The CIE $L^{*} a^{*} b^{*}$ coordinate system is a widely recommended method for evaluating color variations. In the system, the color difference value, $\Delta E$, is expressed as the relative color change between sets of color measurements. ${ }^{11}$ According to Inokoshi et al., values of $\Delta E<$ 1 are regarded as invisible to the human eye. ${ }^{23}$ Values ranging from 1 to 3 are perceptible to the naked eye and values exceeding 3.3 considered clinically unacceptable. ${ }^{5,10,11}$ Therefore, color changes $\Delta E \geq 3.3$ over the course of 4 weeks would be considered clinically unacceptable. In this study, the mean values of the bulk-fill resins are clinically acceptable after 4 weeks, regardless of the polishing system applied.

In this study, the distilled water was maintained at $34^{\circ} \mathrm{C}$ using a thermostat. Rachel et al. reported that average sublingual temperature approximates $37^{\circ} \mathrm{C}$ for most individuals. However, intra-oral temperature could vary under specific condition and site raged from $34.9^{\circ} \mathrm{C}$ to $35.6^{\circ} \mathrm{C}$ over 24 hours. ${ }^{24}$

This study observed the influence of resin types and polishing systems on color stability. However, factors affecting color stability include the type of staining solution, $\mathrm{pH}$, and solution temperature. Therefore, more studies are needed to evaluate the clinical performances of bulk-fill and conventional composite resins exposed to various factors.

\section{Conclusion}

Within the limitations of this study, polishing methods influence the color stabilities of composite resins. The group polished with Sof-Lex Spiral Wheels showed more resistance to discoloration than group polished with PoGo.

\section{Acknowledgements}

This study was supported by A VHS Medical Center Research Grant, Republic of Korea (grant number: VHSMC 18022).

\section{ORCID}

Hye Jin Kim https://orcid.org/0000-0002-7036-1122

Jeong-hee Kim https://orcid.org/0000-0002-9075-1347

\section{References}

1. Schmitt VL, Puppin-Rontani RM, Naufel FS, Nahsan FP, Alexandre Coelho Sinhoreti M, Baseggio W. Effect of the polishing procedures on color stability and surface roughness of composite resins. ISRN Dent 2011;2011:617672.

2. Douglas WH, Craig RG. Resistance to extrinsic stains by hydrophobic composite resin systems. J Dent Res 1982;61:41-3.

3. Shamszadeh S, Sheikh-Al-Eslamian SM, Hasani E, Abrandabadi AN, Panahandeh N. Color Stability of the Bulk-Fill Composite Resins with Different Thickness in Response to Coffee/Water Immersion. Int J Dent 2016;2016:7186140.

4. Rueggeberg FA, Margeson DH. The effect of oxygen inhibition on an unfilled/filled composite system. J Dent Res 1990;69:1652-8.

5. Attar N. The effect of finishing and polishing procedures on the surface roughness of composite resin materials. J Contemp Dent Pract 2007;8:2735.

6. Patel B, Chhabra N, Jain D. Effect of different polishing systems on the surface roughness of nanohybrid composites. J Conserv Dent 2016;19:37-40.

7. Kritzinger D, Brandt PD, De Wet FA. The effect of different polishing systems on the surface roughness of a nanocomposite and a microhybrid composite. SADJ 2017;72:249-57.

8. Munteanu B, Andrian S, Ursu L, Stoleriu S, Iovan G, Ghiorghe CA. Evaluation of surface condition after finishing and polishing of a flowable composite material. Int J Med Dent 2016;6:124-9.

9. Ilie N, Bucuta S, Draenert M. Bulk-fill resin-based composites: an in vitro assessment of their mechanical performance. Oper Dent 2013;38:618-25.

10. Bucuta S, Ilie N. Light transmittance and micromechanical properties of bulk fill vs. conventional resin based composites. Clin Oral Investig 2014;18:1991-2000. 
11. Liberman R, Combe EC, Piddock V, Pawson C, Watts DC. Development and assessment of an objective method of colour change measurement for acrylic denture base resins. J Oral Rehabil 1995; 22:445-9.

12. Ergücü Z, Türkün L, Aladag A. Color stability of nanocomposites polished with one-step systems. Oper Dent 2008;33:413-20.

13. Türkün LS, Türkün M. The effect of one-step polishing system on the surface roughness of three esthetic resin composite materials. Oper Dent 2004; 29:203-11.

14. Lu H, Roeder LB, Powers JM. Effect of polishing systems on the surface roughness of microhybrid composites. J Esthet Restor Dent 2003;15:297-304.

15. Venturini D, Cenci MS, Demarco FF, Camacho GB, Powers JM. Effect of polishing techniques and time on surface roughness, hardness and microleakage of resin composite restorations. Oper Dent 2006;31:11-7.

16. Sideridou I, Tserki V, Papanastasiou G. Study of water sorption, solubility and modulus of elasticity of light-cured dimethacrylate-based dental resins. Biomaterials 2003;24:655-65.

17. Choi MS, Lee YK, Lim BS, Rhee SH, Yang HC. Changes in surface characteristics of dental resin composites after polishing. J Mater Sci Mater Med
2005;16:347-53.

18. Villalta P, Lu H, Okte Z, Garcia-Godoy F, Powers JM. Effects of staining and bleaching on color change of dental composite resins. J Prosthet Dent 2006;95:137-42.

19. Ertaş E, Güler AU, Yücel AC, Köprülü H, Güler E. Color stability of resin composites after immersion in different drinks. Dent Mater J 2006;25:371-6.

20. Thumu J, Kadiyala A, Bollu IP, Ballullaya SV, Devalla $S$. Effect of Staining Solutions on the Color Stability of Conventional and Bulk Fill Nanohybrid Resin Composites: A Spectrophotometric Analysis. J Oper Dent Endod 2017;2:1-5.

21. Buchalla W, Attin T, Hilgers RD, Hellwig E. The effect of water storage and light exposure on the color and translucency of a hybrid and a microfilled composite. J Prosthet Dent 2002;87:264-70.

22. Johnston WM, Kao EC. Assessment of appearance match by visual observation and clinical colorimetry. J Dent Res 1989;68:819-22.

23. Inokoshi S, Burrow MF, Kataumi M, Yamada T, Takatsu T. Opacity and color changes of tooth-colored restorative materials. Oper Dent 1996;21:7380.

24. Moore RJ, Watts JT, Hood JA, Burritt DJ. Intra-oral temperature variation over 24 hours. Eur J Orthod 1999;21:249-61. 


\section{여러 복합레진에서 수분 흡수에 의한 색변화에 연마가 미치는 영향}

\section{김혜진, 김미연, 송병철, 김선호, 김정희*}

한국보훈복지공단 중앙보훈병원 치과보존과

목적: 복합레진의 색조안정성에 있어서 연마가 영향을 주는지 알아보았다.

연구 재료 및 방법: 2 개의 벌크필 레진과 4 개의 복합레진을 $6 \mathrm{~mm}$ 너비, $4 \mathrm{~mm}$ 높이로 제작하여 광중합한 후 $34^{\circ} \mathrm{C}$ 멸균 증류수에 24 시간 보관하고 분광광도계를 이용하여 CIE $L^{*} a^{*} b^{*}$ 값을 측정하였다. 시편을 연마 방법에 따라 대조군(Mylar strip 그룹), PoGo로 연마한 그룹, Sof-Lex Spiral wheels로 연마한 그룹으로 나누었다(n=5). 색측정은 4 주 동안 매 주 시행하였고 실험 기간 동안 시편은 $34^{\circ} \mathrm{C}$ 멸균증류수에 보관하였다. 실험결과는 일반최소자승법으로 통계분석하였다 $(P<0.05)$.

결과: 일반최소자승법 분석에 따르면 Sof-Lex Spiral wheels로 연마한 그룹의 $\Delta E$ 값이 PoGo로 연마한 그룹과 대조군의 $\Delta E$ 값보다 낮게 나타났다 $(P<0.05)$. 복합레진을 연마한 그룹의 $\Delta E$ 값은 연마하지 않은 대조군의 $\Delta E$ 값보다 낮게 나 타났다 $(P<0.05)$. 복합레진 비교시 Filtek Z250과 Filtek Z350 XT Universal restorative는 모든 기간에서 통계적 차이가 나타나지 않았으며 Tetric N-Ceram Bulk Fill은 1, 2, 3주에서 통계적으로 낮은 $\Delta E$ 값을 나타냈다 $(P<0.05)$.

결론: 이번 연구의 한계점을 감안하면 연마 방법은 복합레진의 색조안정성에 영향을 미친다. Sof-Lex Spiral wheels로 연 마한 그룹이 PoGo로 연마한 그룹보다 변색에 더 큰 저항을 보여주었다.

(구강회복응용과학지 2019;35(1):1-10)

주요어: 벌크필레진; 색조 안정성; 복합레진; 연마 방법; Sof-Lex Spiral wheels 